\title{
PENGARUH KONFLIK PERAN GANDA TERHADAP STRES KERJA PADA PEREMPUAN BEKERJA DI PT HASIL RAYA INDUSTRI KARAWANG
}

\author{
Eliana $^{1}$, Linda Mora Siregar ${ }^{2}$, Nur Ainy Sadijah ${ }^{3}$ \\ Email: ps16.eliana@mhs.ubpkarawang.ac.id
}

Fakultas Psikologi Universitas Buana Perjuangan Karawang

\begin{abstract}
The purpose of this study was to determine how high the level of work stress is, how high the level of dual role conflict experienced, and also to find out whether there is an influence between work stress and dual role conflict in women working at PT Hasil Raya Industri Karawang. This research is quantitative research with a nonprobability sampling method and type of sampling using a saturated sampling technique or census with the number of subjects as many as 159 people. The data collection technique is to use a questionnaire or questionnaire with a Likert scale. The results obtained in this study are the influence of multiple roles conflict on work stress in working women at PT. Hasil Raya Industri Karawang.
\end{abstract}

Keywords: Dual role conflict, work stress, working women

\begin{abstract}
Abstrak
Tujuan dalam penelitian ini adalah untuk mengetahui seberapa tinggi tingkat stres kerja, seberapa tinggi tingkat konflik peran ganda yang di alami dan juga untuk mengetahui apakah terdapat pengaruh antara stres kerja dan konflik peran ganda pada perempuan bekerja PT Hasil Raya Industri Karawang. Penelitian ini merupakan penelitian kuantitatif dengan metode pengambilan sampel nonprobability sampling dan jenis sampling menggunakan teknik sampling jenuh atau sensus dengan jumlah subjek sebanyak 159 orang. Teknik yang digunakan untuk mengumpulkan data dalam penelitian ini adalah menggunakan kuesioner atau angket dengan skala likert. Hasil yang di dapatkan dalam penelitian ini adalah adanya pengaruh konflik peran ganda terhadap stres kerja pada perempuan bekerja di PT hasil raya industri karawang.
\end{abstract}

Kata Kunci: Konflik peran ganda, stres kerja, perempuan bekerja

\section{PENDAHULUAN}

Pada zaman sekarang, seiring dengan pesatnya perkembangan industri dan kemajuan teknologi, banyak sekali kita jumpai perempuan tidak lagi menempatkan diri sebagai ibu rumah tangga, melainkan juga ikut bekerja guna membantu memenuhi kebutuhan hidup. Selain itu, saat ini banyak perusahaan yang lebih cenderung mempekerjakan perempuan dari pada laki-laki, karena perempuan dirasa 
lebih tekun dan teliti dalam mengerjakan pekerjaan tertentu. Penyebab perempuan bekerja biasanya dikarenakan oleh faktor ekonomi, pendidikan dan aktualisasi diri (Hermawan, 2019).

Ruslina (2014) menyatakan bahwa perkembangan ekonomi di Indonesia yang semakin pesat membuat kebutuhan rumah tangga semakin meningkat, selain itu kurangnya pendapatan yang dihasilkan suami sebagai kepala rumah tangga dan pencari nafkah, membuat sebagian besar perempuan ikut serta bekerja guna memenuhi kebutuhan keluarga. Faktor pendidikan menjadikan perempuan cenderung memilih untuk bekerja. Latar belakang pendidikan yang minim, tidak menjadi penghalang bagi mereka, karena sejumlah perempuan akan mencari pekerjaan yang sesuai dengan kemampuan yang dimilikinya. Selain itu, kebutuhan untuk menjalin kontak sosial, merasa lebih dihargai dan untuk merealisasikan potensi yang dimiliki membuat perempuan memutuskan untuk bekerja. Aktivitas dalam bekerja mengandung unsur kegiatan sosial, menghasilkan sesuatu dan pada akhirnya bertujuan untuk kebutuhan hidup (Wulandari, 2012) .

Tenaga kerja di Indonesia khususnya perempuan mengalami kenaikan cukup pesat dengan persentasi sebesar 0,06\%, hal ini terlihat dari data Biro Pusat Statistik dimana pada tahun 2019 laju pertumbuhan tenaga kerja perempuan mencapai 55,50 juta orang atau 0,06\% dari tahun 2018 yang mencapai 55,44 juta orang (Badan Pusat Statistika Provinsi Jawa Barat, 2018; 2019). Dari data diatas dapat kita ketahui bahwa saat ini sudah banyak sekali perempuan yang memilih untuk bekerja dan tidak hanya memilih untuk menjadi ibu rumah tangga. Dalam sektor industri domestik, banyak dijumpai perempuan bekerja baik sebagai buruh pabrik, pembantu rumah tangga, buruh cuci dan lain-lain.

Menjadi perempuan yang mempunyai dua tanggung jawab sekaligus tidaklah mudah terutama untuk perempuan yang sudah menikah, selain harus bekerja perempuan juga dihadapkan dengan tanggung jawab lain yaitu mengurus rumah tangga. Bertemunya dua tanggung jawab di waktu yang bersamaan dapat memicu terjadinya stres kerja pada perempuan yang bekerja. Menurut Robbins, (dalam Massie, 2018) stres kerja karyawan adalah kondisi yang muncul akibat adanya interaksi antara manusia dan pekerjaan serta di karakteristikan oleh perubahan manusia yang memaksa mereka untuk menyimpang dari fungsi normalnya.

Mangkunegara (2015) mendefinisikan stres kerja sebagai perasaan tertekan yang di alami karyawan dalam menghadapi pekerjaan. Stres kerja ini tampak dari simptom. Emosi tidak stabil, perasaan tidak tenang, menutup diri, cemas, dan tegang. Biasanya stres kerja disebabkan oleh beban kerja yang berlebihan, waktu kerja yang mendesak, iklim kerja yang tidak nyaman, dan adanya konflik dari internal maupun eksternal karyawan.

PT Hasil Raya Industri Karawang (selanjutnya akan disingkat menjadi PT HRI), dari 680 orang karyawan yang bekerja di PT HRI, 374 orang diantaranya adalah perempuan dan 159 orang adalah karyawan perempuan yang sudah menikah. PT HRI berdiri pada tahun 1978, pada saat itu PT HRI mendirikan pabrik di Tangerang dan pada tahun 2009 seluruh proses produksi dipindahkan ke karawang hingga saat ini. PT HRI bergerak dalam industri kemasan plastik dan memproduksi 
produk-produk seperti botol dan tutup plastik, gelas plastik, jerigen dan preform PET, serta pencetakan dekorasi dan pelabelan.

Berdasarkan hasil wawancara yang dilakukan peneliti kepada beberapa responden yang bekerja di PT HRI menyatakan bahwa, responden sering mengeluh perihal jam istirahat yang tidak teratur dan tidak adanya Backup atau pengganti ketika jam istirahat, hal ini sangat berdampak kepada responden yang harus bekerja meski jam kerja sudah terhitung habis, akibatnya banyak dari responden yang mengeluh karena kelelahan. Pekerjaan yang berat dan sistem kerja shift, membuat para pekerja perempuan mengalami stres kerja, hal ini ditunjukan dengan adanya aspek stres kerja yang timbul akibat pekerjaan, yaitu aspek fisiologis dimana karyawan perempuan mengalami kelelahan fisik, aspek psikologis dimana karyawan perempuan seringkali menjadi mudah tersinggung, menjadi sensitive dan kadang emosi jika sedang kelelahan (Utaminingsih, 2017).

Menurut Aminah (dalam Utaminingsih, 2017) individu yang mendapatkan tuntutan pekerjaan melebihi batas kemampuan, seperti: lembur akan memunculkan kelelahan, ketegangan dan emosi negatif. Selain itu salah satu responden juga mengungkapkan bahwa sudah banyak rekan kerjanya yang berhenti dari pekerjaannya akibat stres kerja yang dialami dan lebih memilih untuk menjadi ibu rumah tangga, dengan alasan sering terjadi konflik dengan suaminya sebagai kepala keluarga akibat kurangnya waktu untuk mengurus rumah tangga. Terbatasnya sumber daya manusia (SDM) dengan pekerjaan yang dirasa tidak seimbang dan peran sebagai ibu rumah tangga yang sama-sama membutuhkan tenaga, waktu dan perhatian juga menjadi penyebab responden yang bekerja di PT HRI kelelahan dalam menjalankan perannya.

Peran sebagai pekerja dalam sebuah organisasi dan peran sebagai istri atau ibu rumah tangga seringkali memicu sebuah konflik tersendiri, dimana pemenuhan tuntutan keluarga dan pekerjaan saling bertentangan. Konflik yang dialami oleh perempuan bekerja bersumber dari tuntutan untuk dapat membagi waktu untuk keluarga dan pekerjaan. Ketika mengalami pertentangan antara tanggung jawab yang dimiliki sebagai ibu rumah tangga dan tugas-tugas yang harus dilakukan sebagai pekerja akan memicu terjadinya konflik peran (Wulandari, 2012).

Hasil penelitian yang dilakukan oleh Ruslina (2014) menunjukan bahwa terdapat hubungan yang kuat antara konflik peran ganda dengan stres kerja pada perempuan bekerja. Artinya semakin tinggi konflik peran ganda yang dijalani maka akan semakin tinggi stres kerja yang dialami oleh perempuan bekerja. Perempuan yang mengalami konflik peran ganda rentan terpapar stres dalam pekerjaan.

Konflik adalah suatu proses terjadinya pertentangan dari suatu pemikiran yang dirasa akan membawa pengaruh yang negatif. Secara umum konflik merupakan bertemunya dua kepentingan yang berbeda dalam waktu yang bersamaan dan dapat menimbulkan efek yang negatif. Konflik peran ganda merupakan suatu bentuk konflik antar peran, dimana peran dalam keluarga dan bekerja saling bertentangan, menjalankan peran dalam pekerjaan menjadi lebih sulit karena juga harus menjalankan peran dalam keluarga. Dengan adanya dua peran ini akan memicu terjadinya stres kerja (Hermawan, 2019). 
Dari uraian di atas, terlihat ada saling keterkaitan antara konflik peran ganda dengan stres kerja pada perempuan bekerja khususnya pada pekerja perempuan yang sudah berkeluarga. Peneliti menganggap perlu dilakukan penelitian mengenai pengaruh konflik peran ganda terhadap stres kerja khusuSnya pada pekerja perempuan yang sudah berkeluarga dan mempunyai anak. Penelitian ini akan dilakukan dengan cara kuantitatif untuk melihat pengaruh konflik peran ganda terhadap stres kerja pada pekerja perempuan dengan judul penelitian "Pengaruh Konflik Peran Ganda Terhadap Stres Kerja Pada Perempuan Bekerja di PT Hasil Raya Industri Karawang".

\section{Landasan Teori}

\section{Konflik Peran Ganda}

Menurut Robbins (2006) konflik merupakan suatu pertentangan atau bertemunya dua kepentingan yang berbeda dalam waktu yang bersamaan dan hal ini dapat menimbulkan efek yang negatif.

Ada beberapa macam konflik peran ganda pada perempuan, yang diantaranya adalah (Apollo \& Cahyadi, 2012) :

\section{Time-based conflict}

Konflik yang timbul karena tuntutan waktu dari peran yang satu mempengaruhi partisipasi dalam peran lain. Konsep-konsep yang termasuk dalam konflik ini di antaranya: waktu bekerja yang terlalu lama, kurangnya waktu untuk pasangan atau anak, dan kegiatan kerja yang tidak fleksibel.

\section{Strains-based conflict}

Konflik ini terjadi disebabkan oleh gejala-gejala stres seperti kelelahan dan mudah marah, yang timbul dari akibat satu peran mengganggu peran yang lain. Konflik ini melibatkan stres dalam keluarga dan pekerjaan, meluapnya emosi yang negatif dan dukungan dari pasangan.

\section{Behavior-based conflict}

Konflik yang terjadi apabila satu peran menuntut individu untuk menampilkan tingkah laku tertentu dan tingkah laku tersebut mempersulit individu dalam memenuhi tanggung jawabnya dalam peran yang lain.

Stoner et al (dalam Ruslina, 2014) menyatakan faktor-faktor yang mempengaruhi konflik peran ganda, yaitu:

1. Time pressure, semakin banyak waktu yang digunakan untuk bekerja maka semakin sedikit waktu untuk keluarga.

2. Family size \& support, semakin banyak anggota keluarga maka konflik akan semakin banyak. Namun semakin banyak dukungan dari keluarga maka konflik akan makin sedikit.

3. Kepuasan kerja, semakin tinggi kepuasan kerja maka konflik yang akan dirasakan semakin sedikit. 
4. Marital \& life statisfaction, ada asumsi bahwa perempuan bekerja memiliki konsekuensi yang negatif terhadap pernikahannya.

\section{Stress Kerja}

Hellrieger dan Slocum (2011) menyatakan stres merupakan perasaan kecemasan atau ketegangan fisik yang terjadi ketika tuntutan atau stresor yang dirasakan individu melebihi kemampuannya untuk mengatasi masalah yang ada.

Wijono (2010), mengungkapkan bahwa terdapat dua jenis stres, yaitu eustress dan distress. Eustress, yaitu hasil respon terhadap stres yang bersifat sehat, positif, dan konstruktif atau bersifat membangun. Ketika tubuh mampu menggunakan stres yang dialami untuk membantu melewati sebuah hambatan dan meningkatkan performa, stres tersebut bersifat sehat, positif dan menantang.

Distres, yaitu hasil dari respon terhadap stres yang bersifat tidak sehat, negatif dan destruktif atau bersifat merusak. Ketika individu mengalami distress, individu tersebut akan cenderung bereaksi secara berlebihan, bingung, dan kurang mampu mengeluarkan performa secara maksimal. berikut :

Wijono (2010) mengemukakan bahwa aspek-aspek stress kerja adalah sebagai

\section{Aspek fisiologis}

Merupakan perubahan yang terjadi pada metabolisme organ tubuh yang termasuk dalam aspek fisik, seperti detak jantung, tekanan darah meningkat, sekresi adrenalin meningkat, timbulnya gangguan perut, kelelahan fisik, timbulnya penyakit kardiovaskuler, timbulnya masalah aspirasi, keringat berlebihan, gangguan kulit dan susah tidur. Stres kerja banyak berpengaruh pada sistem pembuluh jantung dan perut serta berperan dalam gangguan tidur dan menimbulkan kelelahan fisik yang berlebihan.

\section{Aspek psikologis}

Tidak adanya motivasi yang kuat untuk bekerja, aspek ini biasanya terjadi ketika adanya ketidakpuasan terhadap pekerjaan. Yang termasuk dalam aspek psikologis seperti kebingungan, mudah tersinggung, perasaan frustasi, marah, kesal, emosi menjadi sensitif, perasaan tertekan, kemampuan berkomunikasi menjadi berkurang, menarik diri, depresi, menurunnya fungsi intelektual, kehilangan konsentrasi serta kehilangan spontanitas dan kreativitas.

3. Aspek perilaku

Adanya perubahan atau situasi dimana produktifitas seseorang menurun. Gangguan perilaku misalnya bermalas-malasan, menghindari pekerjaan, meningkatnya ketergantungan pada alkohol, melakukan sabotase pada pekerjaan, makan berlebihan sebagai pelarian atau sebaliknya, meningkatnya perilaku beresiko tinggi, agresif serta adanya kecenderungan untuk bunuh diri. 


\section{METODE PENELITIAN}

Metode yang digunakan dalam penelitian ini adalah metode kuantitatif. Metode kuantitatif adalah metode dimana hasil penelitiannya berupa data angka-angka dan analisis menggunakan statistik dan desain penelitian ini bersifat kausal. Dalam penelitian ini populasi adalah perempuan bekerja di PT Hasil Raya Industri Karawang dengan jumlah populasi 159 orang pekerja perempuan.

Sampel adalah bagian dari jumlah dan karakteristik yang dimiliki oleh populasi tersebut. Metode pengambilan sampel yang digunakan pada penelitian ini adalah non-probability sampling dengan menggunakan teknik sampel Jenuh. Menurut Sugiyono (2017) Sampel jenuh adalah teknik penentuan sampel bila semua anggota populasi digunakan sebagai sampel. Istilah lain sampel jenuh adalah sensus, dimana semua anggota populasi dijadikan sampel. Dengan demikian, maka peneliti mengambil $100 \%$ jumlah populasi pekerja perempuan di PT Hasil Raya Industri Karawang yaitu sebanyak 159 orang responden.

Hasil penelitian ini sejalan dengan penelitian sebelumnya yang dilakukan oleh Ruslina (2014) menunjukan bahwa terdapat hubungan antara konflik peran ganda dengan stres kerja pada perempuan bekerja. Artinya semakin tinggi konflik peran ganda yang dijalani maka akan semakin tinggi stres kerja yang dialami oleh perempuan bekerja. Hasil peneltian ini juga sejalan dengan penelitian yang dilakukan oleh Hermawan (2019) yang membuktikan bahwa konflik peran ganda memberikan sumbangan efektif sebesar $24,7 \%$ terhadap stres kerja.

Konflik peran ganda pada penelitian ini memberikan pengaruh sebesar 25,8\% sedangkan sisanya $74,2 \%$ dipengaruhi oleh variabel lain yang tidak diteliti dalam penelitian ini. Tingkat konflik peran ganda menunjukan bahwa dari 159 orang responden yang masuk kategori konflik peran ganda rendah sebanyak 22 orang atau $13,4 \%$, sedangkan responden dengan kategori konflik peran ganda sedang sebanyak 137 orang atau $83,5 \%$.

Konflik yang terjadi antara pekerjaan dan keluarga membuat pekerja perempuan di PT Hasil Raya Industri Karawang tidak dapat menyeimbangkan waktunya sehingga mengalami kelelahan yang kemudian memicu terjadinya stres kerja. Penelitian ini sejalan dengan teori Greenhaus dan Beutell (dalam Apollo \& Cahyadi, 2012) yang menyatakan macam-macam konflik peran ganda pada perempuan timbul karena tuntutan waktu dari peran yang satu mempengaruhi partisipasi dalam peran lain. Konsep-konsep yang termasuk dalam konflik ini seperti, waktu bekerja yang terlalu lama, kurangnya waktu untuk pasangan atau anak, dan kegiatan kerja yang tidak fleksibel. Konflik yang disebabkan oleh gejala-gejala stres seperti kelelahan dan mudah marah, yang timbul dari akibat satu peran mengganggu peran yang lain. Konflik yang melibatkan stres dalam keluarga dan pekerjaan, meluapnya emosi yang negatif dan dukungan dari pasangan. Konflik yang terjadi apabila satu peran menuntut individu untuk menampilkan tingkah laku tertentu dan tingkah laku tersebut mempersulit individu dalam memenuhi tanggung jawabnya dalam peran yang lain. Dari data di atas diketahui bahwa aspek-aspek konflik peran ganda yang berupa tuntutan waktu dari peran yang dijalani, gejala-gejala stres akibat pekerjaan dan keluarga, termasuk tuntutan perilaku dari masing-masing peran 
mempengaruhi secara positif stres kerja pada perempuan bekerja di PT Hasil Raya Industri Karawang.

\section{HASIL DAN PEMBAHASAN}

Tingkat stres kerja menunjukan bahwa dari 159 orang responden yang masuk dalam kategori stres kerja rendah sebanyak 51 orang atau 31,1\%, dan responden dengan kategori stres kerja sedang sebanyak 108 orang atau 67,9\%, dan tidak ada responden yang mengalami stres kerja tinggi maupun stres kerja sangat tinggi. Mangkunegara (2015) menyatakan bahwa stres kerja merupakan perasaan tertekan yang dialami oleh karyawan dalam menghadapi pekerjaan. Stres kerja ini tampak dari simptom, seperti emosi tidak stabil, perasaan tidak tenang, menutup diri, cemas, dan tegang. Sejalan dengan teori yang diungkapkan oleh Wijono (2010) bahwa ada beberapa aspek yang menyebababkan pekerja perempuan di PT Hasil Raya Industri Karawang mengalami stres kerja seperti, aspek fisiologis yaitu perubahan yang terjadi pada metabolisme organ tubuh yang termasuk dalam aspek fisik, seperti detak jantung, tekanan darah meningkat, timbulnya gangguan perut, kelelahan fisik, keringat berlebihan, dan susah tidur. Stres kerja banyak berpengaruh pada sistem pembuluh jantung dan perut serta berperan dalam gangguan tidur dan menimbulkan kelelahan fisik yang berlebihan. Aspek psikologis yaitu, tidak adanya motivasi yang kuat untuk bekerja, aspek ini biasanya terjadi ketika adanya ketidakpuasan terhadap pekerjaan. Yang termasuk dalam aspek psikologis seperti kebingungan, mudah tersinggung, perasaan frustasi, marah, kesal, emosi menjadi sensitif, perasaan tertekan, kemampuan berkomunikasi menjadi berkurang, menarik diri, depresi, menurunnya fungsi intelektual, kehilangan konsentrasi serta kehilangan spontanitas dan kreativitas. Aspek perilaku yaitu, adanya perubahan atau situasi dimana produktifitas seseorang menurun. Gangguan perilaku ini misalnya bermalas-malasan, menghindari pekerjaan, melakukan sabotase pada pekerjaan, makan berlebihan sebagai pelarian atau sebaliknya, dan agresif.

\section{KESIMPULAN}

Berdasarkan analisis data yang sudah dilakukan, maka dapat disimpulkan beberapa hal sebagai berikut:

1. Dalam penelitian ini diketahui bahwa tingkat stres kerja pada perempuan bekerja di PT Hasil Raya Industri Karawang berada pada kategori sedang dengan jumlah persentasi sebesar $65,9 \%$.

2. Dalam penelitian ini diketahui bahwa tingkat konflik peran ganda pada perempuan bekerja di PT Hasil Raya Industri Karawang berada pada kategori sedang dengan jumlah persentasi sebesar $83,5 \%$.

3. Ada pengaruh konflik peran ganda terhadap stres kerja pada perempuan bekerja di PT Hasil Raya Industri Karawang, hal ini ditunjukkan dari hasil analisis menggunakan metode analisis regresi linear sederhana, serta nilai t hitung yang bersifat positif mengandung arti bahwa semakin tinggi konflik peran ganda yang dijalani maka akan semakin tinggi stres kerja yang dialami oleh pekerja 
perempuan dan begitu pula sebaliknya. Pengaruh konflik peran ganda terhadap stres kerja adalah sebesar 25,8\% sedangkan sisanya 74,2\% dipengaruhi oleh variabel lain yang tidak diteliti dalam penelitian ini.

\section{REFERENSI}

Apollo, C. A. (2012). Widya Warta No. 02 Tahun XXXV I/ Juli 2012 ISSN 08541981. Konflik Peran Ganda Perempuan Menikah yang Bekerja ditinjau dari Dukungan Sosial Keluarga dan Penyesuaian Diri.

Azwar, S. (2018). Penyusunan Skala Psikologi. Yogyakarta: Pustaka Pelajar.

Fahmi. I, (2017). Manajemen Sumber Daya Manusia. Teori dan Aplikasi. Bandung. Alfabeta.

Greenhaus \& Beutell. (1985). Sources Of Conflict Between Work And Family Roles. Academy of Management Review.

Handoko. T. (2014). Manajemen Personalia \& Sumber Daya Manusia. Dosen Fakultas Ekonomi dan Bisnis. Universitas Gadjah Mada. Yogyakarta.

Heillriegel, D., \& Slocum, J.W. (2011). Organitational behavior, thirteenth edition. South-Western:Cengage Learning.

Hermawan, B. (2019). Pengaruh Konflik Peran Ganda Terhadap Stres Kerja pada Perawat Wanita Anggota PPNI di RSUD Karawang. Program Studi Psikologi Universitas Buana Perjuangan Karawang.

Indrawan, R., \& Yaniawati, R. P. (2014). Metodelogi Penelitian Kuantitatif, Kualitatif, dan Campuran untuk Manajemen, Pembangunan, dan Pendidikan. Bandung. PT. Refika Aditama.

Kadir. (2015). Statistika Terapan. Jakarta : Rajawali Pers.

Mangkunegara. (2015). Manajemen Sumber Daya Manusia Perusahaan. Bandung. PT Remaja Rosdakarya Offset.

Maria. (2014). http://repository.uin-suska.ac.id/6305/3/BAB\%20II.pdf

Massie, et all. (2018). Pengaruh Stres Kerja Terhadap Kinerja Karyawan pada Kantor Pengelola It Center Manado. Manado: Program Studi Administrasi Bisnis.

Riadi. (2018). $\quad$ https://www.kajianpustaka.com/2018/01/pengetian-jenis-danpenyebab-konflik-peran.html

Robbins, S. P. (2006). Perilaku Organisasi. Alih Bahasa: Benyamin Molan. Edisi Kesepuluh. Penerbit PT. Indeks, Kelompok Gramedia. Jakarta.

Rosyad S.A (2017). Hubungan Konflik Peran Ganda (Work Family Conflict) Terhadap Stres Kerja Perawat Wanita Diruang Rawat Inap, Intensive Care dan IGD RSUD Tugurejo. Departemen Ilmu Keperawatan. Fakultas Kedokteran Universitas Diponegoro. Semarang. 
Ruslina. (2014). Hubungan antara Konflik Peran Ganda dengan Stres Kerja pada Wanita Bekerja. Naskah Publikasi. Surakarta: Fakultas Psikologi Universitas Muhammadiyah.

Spector, P. E. (2006). Industrial and Organizational Psychology: Reaserch and Practice. Hoboken: Jhon Wiley \& Sons, inc.

Sugiyono. (2013). Metode Penelitian Pendidikan Pendekatan Kuantitatif, Kualitatif, dan $R \& D$. Bandung : Alfabeta.

Sugiyono. (2016). Metode penelitian kuantitatif, kualitatif dan R\&D. Bandung: Alfabeta.

Sugiyono. (2018). Metode Penelitian Kuantitatif. Bandung: Alfabeta.

Utaminingsih. (2017). Gender dan wanita karir. Penerbit UB Press. Malang.

Utaminingsih. (2019). Dampak konflik peran ganda dan stres kerja terhadap motivasi dan komitmen dosen wanita pejabat struktural. AKADEMIKA, 17(01).

Wijono, S. (2002). Psikologi Industri \& Organisasi. Jakarta. Kencana Prenada Media Group

Wulandari. (2012). Faktor-faktor Yang Melatarbelakangi Laki-laki Berprofesi Sebagai Perawat. Program Studi Sosiologi. Fakultas Ilmu Sosial Dan Ekonomi. Universitas Negri Yogyakarta. 